\title{
POLA PENYELESAIAN PERSELISIHAN MENURUT RASUL PAULUS DALAM 1 KORINTUS 3:1-9
}

Sarwono

sarwono@sttab.ac.id

\begin{abstract}
Corinthians This letter is a letter written by the Apostle Paul addressed to the church in Corinth in 55 CE during his second missionary journey. The writing of this letter is motivated by several things, one of which is disputes. The city of Corinth was a metropolitan city with a strategic location so that many people came to Corinth to trade. In addition, the city of Corinth was also known for its extraordinary level of crime. All crimes are committed openly there. For Paul, the disputing church is a church that is not yet mature in the faith, so that they are still dominated by the spirit of division, unable to focus on the source of growth. In this case Paul provided a solution to overcome the problem of disputes that occurred among the Corinthians, namely applying the pattern of dispute resolution according to the Apostle Paul. It is hoped that through this article can help the lives of believers in overcoming disputes in the Church.
\end{abstract}

Keywords: $\quad$ Pattern, Settlement, Disputes, Apostle Paul.

Abstraksi: $\quad$ Surat 1 Korintus ini adalah surat yang ditulis oleh Rasul Paulus yang ditujukan kepada jemaat yang ada di Korintus pada tahun 55 M pada saat perjalanan misinya yang kedua. Adapun penulisan surat ini dilatarbelakangi oleh beberapa hal salah satunya adalah perselisihan. Kota Korintus adalah kota metropolitan dengan letaknya yang strategis sehingga banyak orang yang datang ke Korintus untuk berdagang. Selain itu kota Korintus juga dikenal dengan tingkat kejahatannya yang luar biasa. Segala kejahatan dilakukan terang-terangan disana. Bagi Paulus jemaat berselisih adalah jemaat yang belum dewasa didalam iman sehingga mereka masih dikuasi oleh roh pemecah, belum bisa memfokuskan diri pada sumber pertumbuhan. Dalam hal ini Paulus memberikan suatu solusi untuk mengatasi permasalahan perselisihan yang terjadi dikalangan jemaat Korintus, yaitu menerapkan pola penyelesaian perselisihan menurut Rasul Paulus. Diharapkan melalui tulisan ini dapat menolong kehidupan orang percaya dalam mengatasi perselisihan dalam Gereja.

Kata Kunci: $\quad$ Pola, Penyelesaian, Perselisihan, Rasul Paulus.

\section{$\underline{\text { Latar Belakang Masalah }}$}

Gereja adalah satu Tubuh di dalam Kristus karena Tuhanlah yang mempersatukan gereja. Sesuatu yang sudah diperkumpulkan Tuhan tidak boleh dipecahkan oleh manusia, tetapi yang terjadi di dalam kehidupan orang percaya tidak sesuai dengan istilah tubuh Kristus yang adalah satu di dalam persekutuan. Adanya perselisihan di dalam kehidupan orang percaya membuat persekutuan menjadi kendor sehingga terjadilah perpecahan 
didalamnya. Orang percaya adalah milik Tuhan karena orang percaya dipilih Tuhan untuk menjadi tubuhNya. Orang percaya yang tidak kelihatan adalah yang tertuju kepada pribadi seseorang atas dasar pengakuan imannya terhadap Yesus Kristus yang adalah penyelamat. Sedangkan bentuk bangunan dari sebuah organisasi gereja disebut gereja yang kelihatan.

Sepanjang sejarah hingga pada saat ini perselisihan diantara kehidupan orang percaya kerap kali terjadi. Karena adanya perselisihan sehingga membuat persekutuan di dalam gereja menjadi kendor. Banyak hal yang memicu perselisihan. Diantaranya; merasa tidak senang dengan kehadiran orang lain. Agus mengatakan "suasana yang memanas kalau dibiarkan, dapat mengakibatkan perpecahan dan perselisihan satu sama lain."

Seperti halnya yang terjadi di dalam Jemaat yang ada di Korintus dimana mereka mengalami suatu perselisihan sehingga menimbulkan pengelompokan dengan mengatakan "aku dari golongan Paulus dan aku dari golongan Apolos" hal ini merupakan bentuk kehidupan rohani jemaat yang belum dewasa. Dalam hal ini Wesley mengatakan "kamu belum dewasa di dalam Kristus, buktinya kamu masih duniawi sebab kamu menggolonggolongkan diri." 2 Lebih lanjut Matthew juga mengatakan "Ini merupakan bukti bahwa mereka masih bersifat duniawi, bahwa kepentingan dan kesenangan duniawi sudah mengombang-ambingkan mereka terlalu jauh. Agama yang sejati membuat manusia berdamai dan tidak bertikai. Roh pemecah berdasarkan asas-asas manusiawi dan bukan asas-asas agama yang sejati."3

Jemaat yang berselisih adalah jemaat yang hidupnya tidak dipimpin oleh Allah. Itulah yang terjadi di jemaat Korintus. Dalam hal ini pun Howard mengatakan "orang Korintus tidak hidup seperti mereka yang dituntun oleh Roh Allah." ${ }^{4}$ Permasalahan yang seperti ini juga yang kerap kali terjadi di dalam kehidupan berjemaat. Seperti yang dikatakan oleh Matthew "mereka sama sekali belum berdiri teguh di atas dasar pewahyuan ilahi dan belum masuk ke dalam Roh injil, sehingga mereka masih ada di bawah kuasa daging dan perasaan yang rusak sehingga mereka masih tetap bayi di dalam Kristus. ${ }^{5}$

Masalah-masalah di Korintus tampaknya bukanlah sesuatu yang baru muncul karena pertama kali ia berada disana Paulus tidak dapat berbicara dengan orangorang Korintus sebagai bahasa rohani, sebagai orang-orang yang dengan segera memahami pesannya. Paulus sangat menyesal bahwa situasi belum berubah sama sekali! Mereka adalah manusia duniawi, tidak rohani (2:14), duniawi dalam sifat

\footnotetext{
${ }^{1}$ Agus Soehono, Hidup Yang Berkenan, (Jakarta: Gunung Mulia, 2002), 20

2 J. Wesley Brill, Tafsiran Surat Korintus Pertama, (Bandung: Yayasan Kalam Hidup, 2000), 73

${ }^{3}$ Matthew Henry, Tafsiran Surat Roma, I dan II Korintus, (Surabaya: Momentum, 2015), 535

${ }^{4}$ Howard Clark Kee, Alkitab Edisi Studi, (Jakarta: Lembaga Alkitab Indonesia, 2011), 1868

${ }^{5}$ Matthew Henry, Tafsiran Surat Roma, I dan II Korintus ..., 534
} 
dan fikirannya tidak tersentuh dan tidak terdidik oleh Roh Allah, dan masih di bawah kuasa dosa (Rom. 7:14). ${ }^{6}$

Richard juga berpendapat bahwa "penyebab perselisihan dalam gereja tidak lain adalah ketidakdewasaan anggota. Paulus menyimpulkan bahwa penyebab perselisihan jemaat di Korintus adalah ketidakdewasaan orang-orang Kristen di Korintus." 7 Dengan demikian perselisihan yang terjadi di jemaat Korintus karena mereka masih memikirkan hal-hal yang bersifat duniawi akan kesenangan pribadinya sendiri. Itu berarti jemaat yang di Korintus belum sepenuhnya mengalami kedewasaan iman sehingga mereka mengalami permasalahan dalam berjemaat. Penyebab itu semua tidak lain adalah roh pemecah yang ada pada dirinya sendiri.

Pecahnya Gereja timur abad ke-IV diakibatkan oleh karena adanya perselisihan. ${ }^{8}$ Perselisihan tersebut mengenai doktrin natur Kristus. ${ }^{9}$ Hal inilah yang menjadi gejolak semalam 250 tahun. Masa pemerintahan Konstantinus, dalam kekristenan terjadi skisma, yang mengakibatkan perpecahan antara gereja Timur dan gereja Barat. Perpecahan itu terjadi pada $1054 .^{10}$

Pada zaman reformasi gereja juga mengalami perselisihan yang dipelopori oleh bapak-bapak gereja seperti Martin Luther, Johan Calvin, dan Ulrich Zwingli. Adapun masalah yang terjadi pada saat itu dimana jemaat mengagungkan para uskup yang dianggap mampu menghapus dosa manusia. Selanjutnya Jonar menyatakan "di dalam gereja ada suatu aturan yang diterapkan bahwa tokoh agama (pastur atau rohaniwan) dianggap mampu megampuni dosa umat manusia. Jika manusia berdosa, cukup dengan mengadakan pengakuan pada pastur. Sang pastur akan berkata bahwa dosanya sudah diampuni." ${ }^{11}$ Hal inilah yang ditentang oleh para reformator pada saat itu sehingga tercadi perpecahan antara gereja Katolik dengan Protestan.

Dalam sejarah gereja di Asia juga mengalami permasalahan yang serupa khususnya dalam gerakan oikumene di India. Hoke mengatakan "mayoritas besar dari orang-orang yang mengaku diri Kristen tidak mengenal Kristus secara pribadi. Berbagai persaingan dan

\footnotetext{
${ }^{6}$ V. C. Pfitzner, Kesatuan Dalam Kepelbagaian, (Jakarta: BPK Gunung Mulia, 2010), 50

${ }^{7}$ Richard Maruli Daulay, Akar Konflik Gereja Dan Masyarakat, (Jakarta: Dian Utama, 2003), 47

${ }^{8}$ H. berkhof, sejarah Gereja, (Jakarta: Gunung Mulia,2004), 56-57

${ }^{9}$ Ibid.

${ }^{10}$ Jonar S., Sejarah Gereja Umum, (Yokyakarta: ANDI, 2004), 289

${ }^{11}$ Ibid. 308
} 
perpecahan kecil terjadi, plus perselisihan berdasarkan kasta, wilayah, merusak kesaksian dari gereja."12

Begitupun juga yang terjadi di Indonesia ini, ada banyak gereja-gereja yang berdiri akibat dari perpecahan yang diakibatkan oleh perselisihan yang terjadi di dalam gereja itu sendiri. Dalam perhimpunan gereja di Indonesia mengalami perbedaan pendapat sehingga DGD yang bertujuan untuk menciptakan keharmonisan antar gereja mengalami perselisihan dengan DGI/PGI yang merencanakan untuk menyatukan gereja di Indonesia. Jonge mengatakan "berbagai faktor non-teologis, khususnya berhubungan dengan identitas suku-suku, menghambat keesaan, malah menyebabkan perpecahan-perpecahan dalam gereja-gereja anggota DGI." ${ }^{13}$ Menjelaskan bagian ini End mengatakan ;

Setelah Indonesia merdeka, jumlah gereja bertambah besar dan kekeristenan Indonesia tumbuh beraneka ragam. Penyebab yang pertama ialah retaknya beberapa gereja akibat unsur kesukuan/kedaerahan atau faktor lain. Demikianlah di Sumatra Utara lahirlah GKPS (1963), GKPI (1964) dan HKBP-Angkola (kemudian GKPA), yang melepaskan diri dari HKBP. Di Nias, AMIN (1946), ONKP (1950), dan lain-lain. Di Sulawesi GKLB (1966) dan GPIL (1966). ${ }^{14}$

Masalah terbesar yang dapat menimbulkan permasalahan jemaat adalah masalah yang datangnya dari gereja itu sendiri. Permasalahan yang berasal dari dalam dapat meretakkan persekutuan jemaat tetapi permasalahan yang datangnya dari luar akan mempersatukan jemaat.

Jadi untuk menjaga suatu kesatuan di dalam persatuan harus ada sentralnya. Persatuan di dalam persekutuan akan terasa nyaman jika semuanya bersentral kepada Kristus karena Allahlah yang membangun sebuah persekutuan. Berdasarkan latar belakang tersebut makan tulisan ini akan membahas tentang Pola Penyelesaian Per Rasul Paulus Dalam 1 Korintus 3:1-9

\section{POLA PENYELESAIAN PERSELISIHAN MENURUT RASUL PAULUS DALAM 1 KORINTUS 3:1-9}

Dalam bagian ini akan memaparkan pola penyelesaian perselisihan menurut Rasul Paulus dalam 1 Korintus 3:1-9. Paulus adalah misionaris yang juga mendirikan jemaat di Korintus, Marxsen mencatat "bahwa Paulus mendirikan gereja di Korintus pada

\footnotetext{
${ }^{12}$ Donald E. Hoke, Sejarah Gereja asia Volume 1, (Malang: Gandum Mas, 2000). 293

${ }^{13}$ Dr. Christiaan De Jonge, Menuju Keesaaa Gereja, Sejarah Dokumen-dokumen Dan Tema-tema Gerakan Oikumenis, (Jakarta: Gunung Mulia, 2006). 87

${ }^{14}$ Dr. Th. Van den End dan dr, J. Weitjens, S.J. Ragi Cerita 2, Sejarah Gereja Di indonesia 1860an - sekarang, (Jakarta: Gunung Mulia, 1993). 358
} 
perjalanan penginjilan yang kedua." 15 Disisi lain Hakh juga mencatat "Paulus mendirikan jemaat di Korintus setelah melakukan perkerjannya di Filipi, Tesalonika, Berea, dan Athena pada tahun 50 M. Pada awalnya, Paulus tiba di Korintus sendirian (Kis. 18:5), tetapi segera ditemani oleh Silas dan Timotius." 16 Jadi Paulus mendirikan jemaat di Korintus pada waktu ia melakukan perkerjaannya di Filipi, Tesalonika, Berea, dan Athena pada saat perjalanan misinya yang kedua.

Permasalahan yang terjadi di dalam jemaat Korintus ini ialah jemaatnya yang mengelompokan diri menurut bapak rohani mereka. Ada yang mengaku kami dari kelompok Paulus, kami dari kelompok Apolos, kami dari kelompok Kefas, dan kami dari kelompok Kristus (1 Kor. 1:10-12). Sehubungan dengan itu Telhalia mencatat dalam bukunya bahwa jemaat Korintus mengelompokan diri menjadi beberapa bagian, diantaranya:

Pertama Kelompok Paulus. Terdiri dari kaum Libertin. Mereka adalah orang-orang yang telah mendengar kotbah Paulus, tentang kemerdekaan Kristen. Mereka menyimpulkan bahwa begitu mereka dapat hidup sesukanya. Menurut para guru agama Yahudi, itulah yang terjadi jika berita Kristen disampaikan tanpa tuntunan hukum Perjanjian Lama. tentang hal ini, mereka pernah menantang Paulus di Galatia. Sebenarnya Paulus selalu menekankan bahwa sebagai orang kristen, ia selalu menjalankan kewajiban-kewajiban moral. Kedua: Kelompok Kefas, Kelompok ini merupakan kaum legalistik. Mereka, seperti para guru agama Yahudi di Yerusalem, yang berpendapat bahwa kehidupan Kristen berarti mengikuti hukum taurat dengan ketat. Aturan ketat baik menurut upacaya agama maupun secara moral. Ketiga: Kelompok Apolos. Kemungkinan terdiri orang-orang yang mengikuti pandangan Yunani yang klasik. Apolos disebut salam KIS 18:24-28, seorang Yahudi dari Aleksandria. Dia seorang yang fasih berbicara dan sangat mahir dalam soal-soal kitab suci. Keempat: Kelompok Kristus Mereka ini mungkin yang menganggap dirinya $\mathrm{di}$ atas kelompok-kelompok lainnya. Mereka mengkehendaki berhubungan langsung dengan Kristus secara pribadi. Sama seperti hubungan mistik yang mereka alami secara langsung dengan dewa-dewa dalam agama misteri dari Timur. Paulus menjelaskan bahwa tidak ada seorang pun, yang dapat mengaku: Yeus adalah Tuhan, selain Roh Kudus (1 Kor 12:3). Apa yang mereka coba Lakukan ialah menaati satu dewa dan dewa yang lainnya. ${ }^{17}$

Dalam hal yang sama Bergant juga mencatat bahwa "beberapa menyebut diri pengikut Paulus, lainnya lebih suka kepada Apolos yang pandai berbicara,yang lain

\footnotetext{
${ }^{15}$ Willi Marxsen, Pengantar Perjanjian Baru, Pendekatan Kritis Terhadap Masalah-masalahnya (Jakarta: Gunung Mulia, 2008). 77

${ }^{16}$ Pdt. Dr. Samuel Benyamin Hakh, Perjanjian Baru, Sejarah, Pengantar dan Pokok-pokok Teologisnya (Bandung: Bina Media Informasi, 2010). 138

17 Dr. Telhalia, M.Th. Riwayat hidup Paulus. (Banten: An1mage: 2017.). 66
} 
membanggakan Kefas dan ada yang mau mengalahkan mereka dengan mengklaim pengikut Kristus." 18

Jemaat di Korintus tidak hanya berselisih karena mengidolakan siapa pemimpinnya, melainkan ada beberapa masalah yang membuat mereka terpecah belah. Adapun masalah tersebut dicatat oleh John dkk dalam sebuah buku bahwa "mereka terpecah karena soal kepimpinan (1:12), karena standar moral (5:1-8), karena kasus pendakwa dan terdakwa (6:1-8), karena kasus orang kristen yang lemah dan yang kuat (8:7-12), mereka terpecah antara yang kaya dan yang miskin (11;17-22), dan karena karunia Roh (12:12-26)."19

Dari beberapa informasi di atas maka dapat disimpulkan bahwa surat 1 Korintus ini dilatarbelakangi oleh adanya permasalahan yang terjadi di dalam jemaat Korintus sehingga Paulus menulis surat 1 Korintus ini guna untuk menegur mereka supaya tidak hidup dalam persoalan-persoalan duniawi.

\section{Eksegese Surat 1 Korintus 3:1-9}

Dalam bagian ini akan mengeksegese kata-kata penting untuk mendapatkan kajian yang mendalam sehingga dapat memahami pola Rasul Paulus dalam menyelesaikan perselisihan.

\section{Penyebab Perselisihan}

Perselisihan kerap kali terjadi baik di dalam diri sesorang maupun di dalam komunitas atau lingkukan. Perselisihan terjadi karena ada penyebab yang mengakibatkan terjadinya perselisihan. Perselisihan yang terjadi di dalam jemaat Korintus dikarenakan oleh ketidak mampuan mereka untuk menghidupi panggilan mereka sebagai orang yang sudah dimerdekakan oleh Kristus sehingga jemaat Korintus masih menghidupui manusia duniawinya.

\section{Manusia Duniawi}

Manusia duniawi dalam bahasa aslinya memakai kata $\sigma \alpha \rho \kappa l v o \varsigma$ (sarkinos) asal kata dari $\sigma \alpha \rho \xi$ sarx yang berarti daging, bagian dari dunia ini; tidak di bawah kuasa Roh Kudus; manusiawi. ${ }^{20}$ Sutanto mengatakan "itu menunjukan sifat dari manusia." ${ }^{21}$ dengan kasus adjective dative masculine plural no degree. Itu berarti pada waktu itu Paulus

\footnotetext{
${ }^{18}$ Dianne Bergant, Tafsir Alkitab Perjanjian Baru (Yogyakarta: Kanisius, 2002). 281

${ }^{19}$ John Balchim, dkk, Intisari Alkitab (Jakarta: Scripture Union, 2015), 51

${ }^{20}$ Bibleworks7 1Korintus 3:1

${ }^{21}$ Hasan Sutanto, Terjemahan Baru Interlinear Yunani-Indonesia dan Konkordansi Perjanjian baru Jilid I dan II (Jakarta: LAI, 2004). 699
} 
mengeluarkan sifat manusia duniawinya diamana ia tidak bisa lagi membicarakan hal-hal yang rohani untuk jemaat Korintus.

Pfitzne mengatakan bahwa "mereka adalah manusia duniawi, tidak rohani (2:14), duniawi dalam sifat dan pemikirannya, tidak tersentuh dan tidak terdidik oleh roh Allah, dan masih dibawah kuasa dosa (Rom. 7:14)." 22 Itu berarti bahwa jemaat Korintus hidup di dalam kedagingan mereka dimana sifat dan pemikirannya masih dipengaruhi oleh keinginan-keinginan dagingnya sehingga belum dapat menerima asupan rohani yang Paulus berikan.

Dalam hal ini penulis menarik sebuah kesimpulan kecil bahwa penyebab terjadinya perselisihan di dalam jemaat Korintus adalah ketidak mampun mereka akan perbedaan kehidupan manusia rohani dan kehidupan manusia duniawinya. Mereka tidak menghidupi manuisa rohani tetapi lebih menghidupi manusia duniawinya. Sifat duniawi yang mereka hidupi terlihat dalam hidup mereka yang belum dewasa, masih iri hati, dan mengalami suatu perselisihan.

Belum Dewasa: Frase "belum dewasa" dalam bahasa aslinya memakai kata

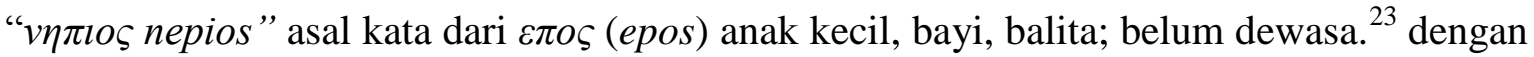
kasus adjective normal dative masculine plural no degree. ${ }^{24}$ Suatu sifat normal yang dimiliki oleh orang Korintus sebagai objek yang seharusnya tidak mereka lakukan. Kata "nepios" ini juga di pakai dalam Galatia 4:1. Jemaat di Korintus dikatakan nepios atau anak kecil, bayi, balita dan belum dewasa karena mereka masih belum bisa mencerna pengajaran-pengajaran kekeristenan yang mendalam di dalam kehidupan mereka pada saat itu.

Hal ini juga di catat oleh Paulus dalam 1 Kor. 14:20 "saudara-saudara janganlah seperti anak-anak dalam pikiranmu". Disini sangat jelas bahwa Paulus memberikan suatu arahan agar jemaat di Korintus berpikir dewasa untuk menyikapi segala sesuatu, karena dari situlah dapat di lihat pertumbuhan seseorang di dalam Kristus. Ketidakdewasaan menunjukan ketidak mampuan seseorang untuk bertumbuh di dalam Kristus. Brill dalam bukunya mengatakan istilah "belum Dewasa" dalam ayat ini bukan berarti "mereka belum bertobat dan percaya kepada Yesus Kristus, ataupun baru diselamatkan, melainkan mereka

\footnotetext{
${ }^{22}$ V.C. Pfitzner, Ulasan Atas 1 korintus, Kesatuan dalam Kepelbagaian..., 50

${ }^{23}$ SABDA, 1 Korintus 3:1

${ }^{24}$ Bibleworks7 1 Korintus 3:1
} 
tidak bertumbuh atau tidak maju di dalam Kristus. ${ }^{25}$ dari sisi inilah jemaat di Korintus di nilai belum dewasa oleh rasul Paulus.

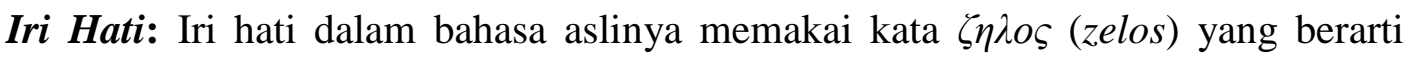
cemburu. ${ }^{26}$ Dalam terjemahan New English Translation "jealousy" dan dalam King James Verson "envying". Sedangkan dalam Terjemahan Lama "ada dengki" 27 . Jadi dapat diartikan bahwa ketidak dewasaan jemaat Korintus terlihat dalam tingkah laku mereka yang masih iri hati terhadap yang lainnya. Kecemburuan terjadi menunjukan adanya dengki terhadap orang lain.

Jika kita melihat dalam Gal. 5:20 bahwa iri hati ini adalah bagian dari perbuatan daging, dan di dalam Rom. 13:13; Yak. 3:14 Paulus kembali menegaskan bahwa perselisihan dan iri hati jangan sampai terjadi di dalam kehidupan orang percaya. Bahkan dalam 2 Kor 12:20 Paulus mengkhawatirkan hal ini terjadi di dalam kehidupan jemaat. Hale mengatakan dalam bukunya bahwa "jealousy and quarreling does not occur among mature spiritual christians (kecemburuan dan pertengkaran seharusnya tidak terjadi di antara kekristenan yang dewasa rohani.),28

Perselisihan: Kata perselisihan dalam bahasa aslinya memakai kata $\varepsilon \rho \iota \varsigma$ (eris) yang berarti percekcokan, persaingan. Dengan bentuk noun nominative feminine singular. ${ }^{29}$ Kata benda yang di pakai untuk pengganti orang pertama. Dalam terjemahan Firman Allah Yang Hidup "berpecah-pecah menjadi kelompok-kelompok yang saling bertentangan." Dalam terjemahan American Version "strife" (perselisihan/percecokan). Dalam Terjemahan Sederhana Indonesia "bertengkar". ${ }^{30}$ Itu berarti bahwa perselisihan ini merupakan sesuatu yang sangat berbahaya bagi setiap perkumpulan. Kelompok akan terpecah karena perbedaan pendapat sehingga dapat menimbulkan suatu pertengkaran.

Dalam Titus 3:9 "Tetapi hindarilah persoalan yang dicari-cari dan yang bodoh, persoalan silsilah, percekcokan dan pertengkaran mengenai hukum Taurat, karena semua itu tidak berguna dan sia-sia belaka" Paulus memberi nasehat bahwa perselisihan dan pertengkaran harus di jauhkan dari kehidupan orang percaya.

Dalam hal ini Daulay mengatakan dalam bahwa "Orang Kristen di Korintus bercekcok dan bertengkar. mereka semua ingin mempertahankan kelompok kecil beserta

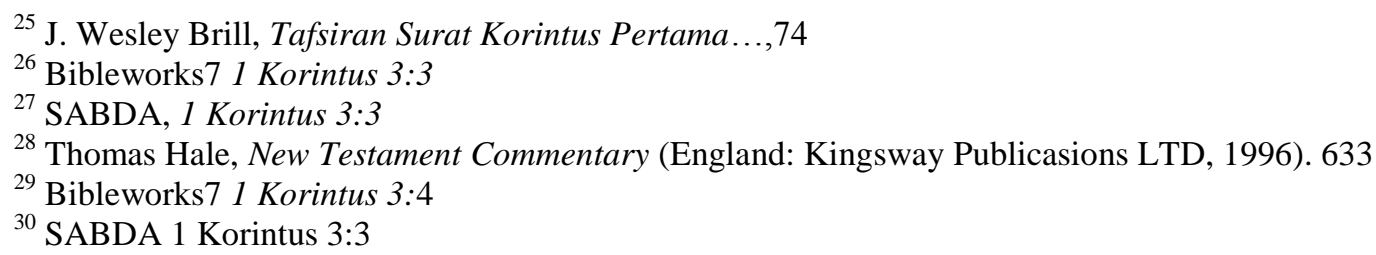


pemimpin kesayangan mereka masing-masing." ${ }^{31}$ Adalah lebih baik untuk menghindari terjadinya perselisihan di dalam gereja adalah jemaat yang mau bertumbuh atau mau mengenakan manusia rohaninya.

\section{Manusia Rohani}

Kata "Rohani" dalam bahasa aslinya memakai kata $\pi v \varepsilon v \mu \alpha \tau \imath \kappa o \varsigma$ (pneumatikos) adjective dative masculine plural no degree, asal kata dari $\pi v \varepsilon v \mu \alpha$ pneuma yang berarti Roh. ${ }^{32}$ Suatu sifat yang di miliki oleh Paulus yaitu Roh yang sama yang dimiliki oleh orang jemaat Korintus juga. Peneumatikos adalah suatu sifat yang ada pada diri orang percaya yang didalamnya ada kepekaan terhadap Roh dan ia senantiasa dipimpin oleh Roh. Dalam teks ini Paulus tidak dapat berbicara dengan manusia rohani dikarenakan kondisi kerohanian Jemaat Korintus yang bisa dikatakan belum bertumbuh.

Disamping itu Pfitzne juga berpendapat bahwa "Paulus tidak dapat berbicara dengan orang-orang Korintus sebagai manusia rohani, sebagai orang-orang yang dengan segera memahami pesannya." ${ }^{33}$ Hal ini menunjukan bahwa pesan rohani tidak dapat disampaikan kepada mereka yang belum dapat menerimanya.

\section{Pengkultusan Individu}

Dalam ayat 4 ini kita bisa melihat bahwa jemaat di Korintus sedang mengalami perbedaan pendapat tentang pemimpin mereka. Frase aku dari golongan Paulus dan aku dari golongan Apolos itu berarti sebagian jemaat memihak kepada Paulus dan sebagiannya lagi memihak kepada Apolos. Siapakah Paulus dan siapakah Apolos sehingga mereka menggolongkan diri menurut kedua tokoh ini.

Penyebab terjadinya perselisihan ialah ketidak dewasaan jemaat. Paulus menyimpulkan bahwa penyebab perselisihan di Korintus adalah karena kitdakdewasaan orang-orang Kristen di Korintus. ${ }^{34}$ Jadi penyebab terjadinya perselisihan dikarenakan jemaat Korintus yang masih hidup dalam keduniawian. Mereka masih belum bisa membedakan mana kehidupan manusia rohani dan mana kehidupan duniawi sehingga mereka belum mengalami kedewasaan iman. Ketidakdewasaan iman ini juga menimbulkan iri hati terhadap satu dengan yang lain sehingga ada perselisihan dan pengelompokan individu.

\footnotetext{
${ }^{31}$ Richard Daulay, firman Hidup 70 (Jakarta: Gunung Mulia, 2008). 63

${ }^{32}$ Bibleworks7 1Korintus 3:1

${ }^{33}$ V.C. Pfitzner, Ulasan Atas 1 korintus, Kesatuan dalam Kepelbagaian..., 50

${ }^{34}$ Daulay. Firman Hidup 10 (Jakarta: Gunung Mulia, 2008). 63
} 


\section{Pola Penyelesaian Perselisihan}

Dalam bagian ini penulis akan memamaparkan tentang pola penyelesaian perselisihan yang dikemukakan oleh Rasul Paulus kepada jemaat Korintus. Adapun pola penyelesaiannya sebagai berikut.

\section{Memahami Firman}

Pemahaman akan Firman merupakan bagian dari kehidupan tiap orang percaya. Karena hanya dengan memahami Firman orang percaya akan memiliki suatu kesadaran akan sumber pertumbuhan iman. Paulus dengan jelas menegaskan bahwa hanya Allah sumber pertumbuhan orang percaya.

\section{Allah Sumber Pertumbuhan}

Kata "pertumbuhan” dalam bahasa aslinya memakai kata " $\alpha v \xi \alpha v \omega$ (auxano)" yang berarti berkembang, bertambah, bertambah besar. ${ }^{35}$ Dalam terjemahan New English Translation "but God caused it to grow" (tetapi Allah penyebab untuk bertumbuh). Sedangkan dalam terjemahan Firman Allah Yang Hidup "tetapi Allah, dan bukan kami, yang menumbuhkannya". Dalam terjemahan AV "but God gave the increase" (tetapi Allah yang memberi peningkatan). ${ }^{36}$

Allah yang memberikan pertumbuhan, kita dapat melihatnya dalam Maz. 92:1315; Yes. 55:5; Yoh 15:5; Yer 2:21; 11:17. Disini menjelaskan bahwa pertumbuhan itu datangnya dari Allah, Allah adalah sumber dari pertumbuhan orang percaya. Oleh sebab itu Paulus menegaskan bahwa Allah yang memberi pertumbuhan, mereka hanyalah pekerja Allah yang akan menerima upah yang sesuai dengan perkerjaannya (1 Kor. 3:9).

Pertumbuhan iman yang benar adalah pertumbuhan iman yang terletak pada dasar yang benar. Jadi untuk menghindari suatu perselisihan haruslah memahami Firman Tuhan, karena pemahaman akan Firman Tuhan akan menyadarkan tiap-tiap orang akan keberadaannya sebagai manusia berdosa, dan akan memfokuskan dirinya kepada Tuhan sehingga tidak memikirkan hal-hal yang bersifat duniawi, dan mempersoalkan hal-hal yang duniawi.

\section{Memahami Peranan Pemimpin}

Pentingnya memahami peranan tiap-tiap pemimpin karena adanya perbedaan dari keberadaan mereka dan tugas-tugas mereka. Seperti yang ditegaskan oleh Rasul Paulus bahwa pemimpin memiliki masing-masing peranan dalam melayani Tuhan. Paulus sebagai penanam dan Apolos sebagai penyiram.

\footnotetext{
${ }^{35}$ Bibleworks7 1 Korintus 3:6

${ }^{36}$ SABDA, 1 Korintus 3:6
} 


\section{Aku menanam}

Kata "menanam" dalam bahasa aslinya memakai kata $\varphi v \tau \varepsilon v \omega$ (phuteuo) yang artinya membuka, dengan kasus verb indicative aorist active 1 st person singular. ${ }^{37}$ Yang menyatakan suatu perkerjaan orang pertama tunggal terjadi sekali berdampak terusmenerus. Dalam terjemahan America Verson frase "aku menanam" memakai frase "I have planted". Sedangkan dalam Firman Allah Yang Hidup "Pekerjaan saya ialah menanam benih dalam hati Saudara". ${ }^{38}$ Frase ini menunjukan bahwa Paulus menegaskan bahwa ia yang memulai pelayanan di Korintus. "aku menanam" tersirat dalam Kis. 18:4-11; 1 Kor. 4:15; 9:1; 15:1 di sini kita dapat melihat bahwa Paulus menyatakan dirinya sebagai pembrita Firman Tuhan, itu berarti bahwa ia menanam benih Firman pada orang-orang yang ia layani pada saat itu.

Sehubungan dengan itu Knight mencatat bahwa "Gereja di Korintus, adalah hasil perkabaran Injil Paulus sendiri." 39 Simanjuntak juga mengatakan "aku menanam menunjukan bahwa Paulus adalah penginjil pertama di Korintus (bnd Rom 15:20)." "40 Jadi istilah sebutan Paulus tentang aku menanam mengandung arti bahwa Paulus adalah pemberita Firman.

\section{Apolos menyiram}

Frase "Apolos Menyiram" dalam bahasa aslinya memakai kata " $\pi 0 \tau \imath \zeta \omega$ (potizo)" yang berarti "mengairi", dalam bentuk verb indicative aorist active $3 r$ person singular. ${ }^{41}$ Yang menyatakan suatu perkerjaan orang ketiga tunggal terjadi sekali berdampak terusmenerus Dalam terjemahan AV "Apollos watered". ${ }^{42}$ Kata ini merupakan penegasan bahwa Apolos yang merawat apa yang sudah ditanam Paulus. Itu berarti bahwa Apolos melanjutkan pelayanan Paulus di Korintus.

Pfitzner dalam bukunya mengatakan bahwa "Paulus yang menanam benih firman, sementara apolos yang datang kemudian menyiram benih yang sedang tumbuh, atau dari cerita yang kedua membangun dasar yang telah diletakan Paulus (9). ${ }^{, 43}$ Itu berarti bahwa Apolos adalah orang kedua yang melayani jemaat Korintus setelah Paulus, dengan kata lain ia melanjutkan pelayanan Paulus.

\footnotetext{
${ }^{37}$ Bibleworks7 1 Korintus 3:6

${ }^{38}$ SABDA, 1 Korintus 3:6

${ }^{39}$ George W. Knght, The Ilusatrated (Jakarta: Gunung Mulia,2016). 349

${ }^{40}$ A. Simanjuntak, Tafsiran Alkitab Masa Kini 3..., 483

${ }^{41}$ Bibleworks7 1 Korintus 3:6

${ }^{42}$ SABDA, 1 Korintus 3:6

${ }^{43}$ V.C. Pfitzner, Ulasan Atas 1 korintus, Kesatuan dalam Kepelbagaian...,50
} 


\section{Memahami Pengajaran}

Pentingnya memahami pengajaran juga berdampak dalam kepribadian seseorang. Pribadi seseorang akan membaik jika ia sendiri dengan baik menerima atau memahami tiap-tiap pengajaran yang dapatkan, begitupun sebaliknya pribadinya akan tidak baik jika ia tidak memahami pengajaran dengan baik. Dalam teks ini Paulus menjabarkan ada beberapa pengajaran yang harus dipahami oleh jemaat, diantaranya:

\section{Kawan Sekerja Allah}

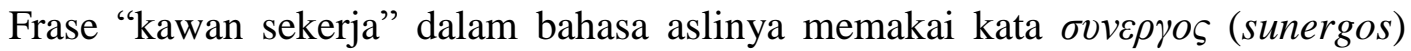
yang berarti "bekerja bersama", dengan kasus adjective nominative masculine plural no degree. ${ }^{44}$ Kata ini dipakai untuk penganti orang jamak yang menunjukan tidak sederajat. Dalam terjemahan BIS "Kami adalah orang-orang yang sama-sama bekerja untuk Allah". Dalam terjemahan AV "For we are labourers together with God". Dalam terjemahan TL "Karena kami orang bekerja bersama-sama dengan Allah". ${ }^{4}$

Kawan sekerja Allah berarti mereka yang bersama-sama menjadi pelayan untuk pembrita Firman dan perkerjaan mereka adalah perkerjaan untuk kemuliaan bagi nama Tuhan. Hal ini dapat di lihat dalam: Mar. 16:20; 2 Kor. 6:1; 1 Tes. 3:2.

Menurut sembiring ada dua cara untuk memahami bagian pertama ayat ini. "pertama: kalimat Yunaninya di sini dapat berarti "kami adalah rekan sekerja Allah, yaitu kami berkerja bersama Allah". Atau kedua: "kami merupakan rekan kerja dalam pelayanan Allah (atau melayani Allah)". Ada juga yang menerjemahkan "kami berkerja bersama-sama dan kami berkerja bagi Allah". 46

Jadi Paulus dan Apolos merupakan alat yang dipakai Tuhan untuk mengerjakan apa yang telah dipercayakan Tuhan kepada mereka, oleh sebab kita Paulus menyatakan diri mereka sebagai pekerja Tuhan yang berkerja di ladang Tuhan.

\section{Ladang Allah}

Kata "ladang" dalam bahasa aslinya memakai kata $\gamma \varepsilon \omega \rho \gamma$ เov (georgion) yang berarti "ladang" dengan kasus noun nominative neuter singular common. ${ }^{47}$ Dalam terjemahan FAYH "Saudara sekalian adalah kebun Allah, bukan kebun kami”. ye are God's husbandry. ${ }^{48}$ Dalam Yes. 61:3 dijelaskan bahwa orang percaya adalah tanaman Tuhan untuk memperlihatkan keagunganNya. Howard mengatakan dalam bukunya "Allah

\footnotetext{
${ }^{44}$ Bibleworks7 1 Korintus 3:9

${ }^{45}$ SABDA, 1 Korintus 3:9

${ }^{46}$ M.K. Sembiring, Pedoman Penafsiran Alkitab Surat Paulus Yang Pertama Kepada Jemaat Di Korintus..., 81-82

${ }^{47}$ Bibleworks7 1 Korintus 3:9

${ }^{48}$ SABDA, 1 Korintus 3:9
} 
menanam Israel di tanah perjanjian-Nya sehingga umat menjadi keadilan Tuhan." ${ }^{49}$ Jadi orang percaya adalah milik Allah.

\section{Bangunan Allah}

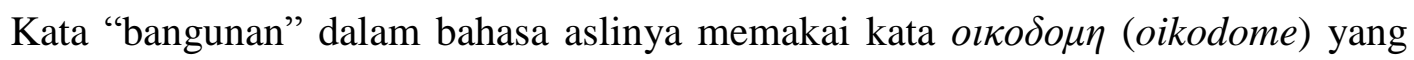
berarti "suatu tempat kediaman". Dalam terjemahan FAYH " Saudara adalah rumah Allah, bukan rumah kami”. Paulus katakan bahwa jemaat Korintus adalah bangunan Allah, itu berarti orang percaya adalah bait Allah tempat kediaman Allah. Hal ini juga bisa di lihat dalam Ef. 2:20-22 dan 1 Ptr. 2:5 yang menjelaskan bahwa orang percaya adalah banguan Allah yang di bangun di atas dasar batu penjuru, yaitu Yesus Kristus. Jadi gereja adalah bangunan Allah di mana jemaat dibangunNya untuk kediamaNya sendiri.

\section{KESIMPULAN}

Gereja tidak hanya berbicara fisik atau gedung tetapi lebih dari itu gereja adalah pribadi orang percaya. Gereja merupakan tubuh Kristus yang tidak dapat dipisahkan, Kristus memanggil orang percaya dari kegelapan menuju terangNya yang ajaib dengan satu tujuan yaitu untuk masuk dalam persekutuan dengan Allah. Kristus sendiri adalah kepala di dalam gereja tersebut dan bukan hanya itu saja Kristus juga adalah dasar dari bangunan gereja (1 Kor. 3:10-11; 1 Ptr. 2:6; Mat. 16:18).

Masalah yang kerap kali terjadi di dalam tubuh Kristus itu sendiri adalah masalah perselisihan. Perselisihan merupakan suatu masalah yang kerap kali terjadi baik di dalam diri seseorang maupun antar kelompok yang menyebabkan ketidakselarasan, bahkan berdampak kepada perpecahan jemaat maupun gereja. Perselisihan kerap kali terjadi di dalam kehidupan orang percaya oleh karena ketidak dewasaan iman jemaat dan para pelayan Tuhan yang masih mementingkan hal-hal duniawi sehingga hati dan pikirannya di kuasai oleh roh pemecah. Seperti halnya yang terjadi di dalam jemaat Korintus yang mengalami perselisihan akan penggolongan tiap-tiap individu.

Sebagai misionaris Paulus mendirikan jemaat di Korintus pada perjalanan misinya yang kedua. Surat 1 Korintus ditulis oleh Rasul Paulus pada saat ia berada di Efesus tahun $55 \mathrm{M}$, surat ini ia tulis sebelum hari raya Pentakosta. Surat ini di latar belakangi oleh adanya permasalahan yang terjadi di dalam jemaat Korintus, khususnya dalam pasal 3:1-9 permasalahan yang terjadi adalah adanya perselisihan di mana ada jemaat yang beranggapan bahwa "aku dari golongan Paulus, aku dari golongan Apolos".

\footnotetext{
${ }^{49}$ Howard Clark Kee, Alkitab Edisi Studi..., 1180
} 
Dengan adanya permasalahan ini maka Paulus memberikan suatu nasehat untuk menyelesaikan permasalahan perselisihan ini. Cara atau pola yang Paulus gunakan dalam menyelesaikan perselisihan adalah (1). Memahami Firman, dengan menyadarkan mereka akan dasar dari pertumbuhan. Paulus mengungkapkan bahwa bukan yang menanam atau yang menyiram yang memberikan pertumbuhan melainkan Allah sendirilah yang memberikan pertumbuhan. (2). Memahami peranan pemimpin, di sini Paulus menjelaskan bahwa setiap pemimpin yang melayani terdapat perbedaan dalam tanggung jawab pelayanan. Paulus sebagai penabur Firman yaitu dialah yang memulai pelayanan di Korintus, sedangkan Apolos menyiram, itu berarti Apolos melanjutkan dari pelayanan yang sudah dilakukan Paulus, di samping itu Paulus juga mengatakan bahwa mereka adalah pekerja biasa yang di pakai Tuhan untuk menumbuhkan iman jemaat dalam kata lain Allah sumber pertumbuhan. (3). Memahami pengajaran, dalam hal ini Paulus menekankan akan posisi antara pekerja Allah dengan ladang dan bangunan Allah. Paulus dan Apolos berkerja sama untuk melakukan tugas yang dipercayakan Allah kepada mereka untuk melayani jemaat Korintus, sedangkan jemaat Korintus sendiri adalah milik Allah dan tempat kediaman Allah.

Dengan ketiga pola ini yaitu: memahami Firman, memahami peranan pemimpin, dan memahami pengajaran. Paulus menyadarkan jemaat Korintus bahwa mereka adalah milik Tuhan yang seharusnya bertumbuh berdasarkan sumber pertumbuhan itu yaitu Allah, bukan untuk mengolongkan diri menurut siapa pemimpinnya. 
Balchim John dkk,

\section{DAFTAR PUSTAKA}

$2015 \quad$ Intisari Alkitab, Jakarta: Scripture Union Indonesia

Benyamin Hakh, Samuel,

2010 Perjanjian Baru, Sejarah, pengantar dan pokok-pokok Teologisnya

Bandung: Bina Media Informasi

Berkhof, H., 2004 Sejarah Gereja, Jakarta: GunungMulia

Bergant, Dianne, 2002 Tafsiran Alkitab Perjanjian Baru Yokyakarta: Kanisius

C. Pfitzner,V., $2010 \quad$ Kesatuan Dalam Kepelbagaian, Jakarta: BPK Gunung Mulia

Clark Kee, Howard, 2011

Alkitab Edisi Studi, Jakarta: Lembaga Alkitab Indonesia

De Jonge, Christian, 2006

Menuju Keesaaan Gereja, Sejarah Dokumen-dokumen Dan Tematema Gerakan Oikumenis, Jakarta: Gunung Mulia

E. Hoke, Donald, $2000 \quad$ Sejarah Gereja Asia Volume 1, Malang: Gandum Mas

Henry, Matthew, 2015 Tafsiran Surat Roma, I dan II Korintus, Surabaya: Momentum

Hale, Thomas, 1996

K. Sembiring M., 2010 Pedoman Penafsiran Alkitab Surat Paulus Yang Pertama Kepada Jemaat Di Korintus, Jakarta: LAI

Marxsen, Willi, 2008 Pengantar Perjanjian Baru, Pendekatan Kritis terhadap masalahmasalahnya, Jakarta: Gunung Mulia

Maruli Daulay, Richard,

New Testament Commentary, England: Kingsway Publicasions LTD $2003 \quad$ Akar Konflik Gereja Dan Masyarakat, Jakarta: Dian Utama 2008 Firman Hidup 70, Jakarta: Gunung Mulia.

Situmorang, Jonar, 2004

Sejarah Gereja Umum, Yokyakarta: ANDI

Sutanto, Hasan, 2004 Terjemahan Baru Interlinear Yunani-Indonesia dan Konkordansi

Soehono, Agus, Perjanjian baru Jilid I dan II, Jakarta: LAI

2002 Hidup Yang Berkenan, Jakarta: Gunung Mulia

Telhalia, 2017 Riwayat hidup Paulus. Banten: An1mage.

Van den End, Th., dan J. Weitjens, S.J.

1993 Ragicarita 2, SejarahGereja Di indonesia 1860an - sekarang, Jakarta: GunungMulia

W. Knight, George, $2016 \quad$ The Ilusatrated Jakarta: Gunung Mulia.

Wesly Brill, J., 2000 Tafsiran Surat Korintus Pertama, Bandung: Yayasan Kalam Hidup 